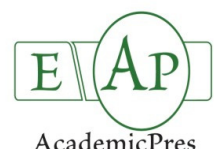

\title{
Chemical Composition, Antioxidant, Anticancer Properties and Toxicity Evaluation of Leaf Essential Oil of Cupressus sempervirens
}

\author{
Sayed A. FAYED \\ CairoUniversity, Faculty of Agriculture,BiochemistryDepartment 12613,Cairo,Egypt;sayedfayed@yahoo.com
}

\begin{abstract}
The essential oil isolated by hydro-distillation from Cupressus sempervirens (Cypress) leaves was analysed by GC-MS and tested for antioxidant and in vitro as well as in vivo anticancer activities. In addition, the toxicity effect of the essential oil was studied using normal Swiss mice. Eighteen components of Cypress essential oil were identified and the main essential oil components were $\alpha$-pinene (29.21\%), $\delta 3$-carene (18.92\%), $\alpha$-cedrol (12.25\%), $\alpha$-terpinolene (7.66\%) and limonene (5.50\%). Cupressus sempervirens essential oil was able to reduce the stable, purple-colored radical DPPH into yellow-colored DPPH reaching $50 \%$ of reduction with $\mathrm{IC}_{50}$ value $=290.09 \mathrm{\mu g} \mathrm{mL}^{-1}$. The in vitro anticancer activity of the essential oil was studied against two human promyelocytic leukemia cell lines (HL-60 and NB4) and experimental animals model cancer cell line (EACC). Cypress essential oil exerted the highest cytotoxic activity with a $\mathrm{LC}_{50}$ of $333.79 \mu \mathrm{g} \mathrm{mL} \mathrm{L}^{-1}$ against NB 4 followed by HL-60 and $\mathrm{EACC}$ cell lines ( $\mathrm{LC}_{50}$ of 365.41 , and $372.43 \mu \mathrm{g} \mathrm{mL}{ }^{-1}$, respectively). Regarding in vivo anticancer study, pre-initiation treatment with the essential oil was more effective than initiation and post-initiation treatments respectively on the tumor (EACC) transplanted female mice (increase lifespan (\%), decrease total EACC number and increase dead cells). In toxicity study, serum urea, transaminases and lactate dehydrogenase were increased. The results obtained from this study showed that the Cypress essential oil possesses antioxidant and anticancer properties, takinginto consideration its mild toxicity.
\end{abstract}

Keywords: Cypress, essential oil, DPPH, HL-60, NB4, EACC, rat

\section{Introduction}

Cancer is the second largest single cause of death claiming over six million lives every year worldwide (Loizzo et al., 2008). Cancer is a complex disease that comprises specific hallmarks. They include sustaining proliferative signaling, evading growth suppressors, resisting cell death, enabling replicative immortality, inducing angiogenesis, and activating invasion and metastasis, apart from reprogramming of energy metabolism and evading immune destruction (Hanahan and Weinberg, 2011; Wishart, 2015).

Oxidative stress is defined as an imbalance between the generation of free radicals in particular reactive oxygen species (ROS) and endogenous antioxidant defense mechanisms (Sies, 1986). Elevated levels of ROS and peroxides have been reported to be implicated in the pathogenesis of a wide variety of disorders such as cancer, diabetes, aging, cardiovascular disease and neurodegenerative diseases (Pham-Huy et al., 2008; Mani, 2015).

Historically, natural products in the field of anticancer research has made significant achievements, over $60 \%$ of the clinical use of anticancer drugs originate from natural products (Seelinger et al., 2012). Plants have been the main resources in traditional medicine and natural products are considered as important sources of antitumor drugs (Song et al., 2014).
Essential oils as natural products are complex chemical mixtures that consist of several types of molecules. Most of the volatile constituents of essential oils are terpenoid derivatives (Emami et al., 2011). A wide spectrum of biological activities have been reported for essential oils including antioxidant, antibacterial, antiviral, antifungal, anticancer, anticonvulsant, spasmolytic, expectorant, immunomodulatory and antidiabetic activities (Lang and Buchbauer, 2012).

Cupressus sempervirens commercially known as "Cypress", a medium-sized evergreen tree to $35 \mathrm{~m}$ belongs to the family Cupressaceae, is a species of Cypress native to the eastern Mediterranean region (Tapondjou et al., 2005; Alkurdi and Supuka, 2015). Cupressus sempervirens is medicinal plant and act as expectorant and astringent and used externally for treating coughs and bronchitis. In addition, the extract of the Cypress is incorporated in preparations (ointments and suppositories) used to treat haemorrhoids and varicose veins. It is also used as anthelmintic, antipyretic, antirheumatic, antiseptic, balsamic and vasoconstrictive (Duke, 2008). Essential oils obtained from Cupressus sempervirens were reported to have antiseptic, aromatherapeutic, astringent, anti-inflammatory, antioxidants, antimicrobial (Boukhris et al., 2012) and antiviral activities (Amouroux et al., 1998). Elansary et al. (2012) revealed that the Cupressus sempervirens leaves essential oil is new promising potential sources of antioxidants and antibacterial compounds. 
The antioxidant activity and anticancer activity of Cypress leaves essential oil in Egypt or the world is not well studied until now (Loizzo et al., 2008; Elansary et al., 2012). Sequentially, the present study aimed to analyse the chemical composition of Cypress leaves essential oil using GC-MS and to elucidate its antioxidant activity (using DPPH assay) and anticancer activity against two human promyelocytic leukemia cell lines (HL-60 and NB4) and Ehrlish ascites carcinoma cells (EACC). In addition, the study investigated the possible deleterious effects of the essential oil from Cypress leaves.

\section{Materials and Methods}

\section{Plant material}

The leaves of Cupressus sempervirens L. (Cypress) (family: Cupressaceae) were collected from the garden of Ornamental Department, Faculty of Agriculture, Cairo University, Giza, Egypt. Identification of the species was carried out by Botanists in Botany Department, Faculty of Agriculture, Cairo University.

\section{Essential oil extraction}

The essential oil of Cypress leaves $(100 \mathrm{~g})$ was extracted by hydrodistillation using Clevenger-type apparatus for $4 \mathrm{~h}$. Hydrodistillation were carried out in triplicate. The essential oil was collected and dried over anhydrous sodium sulphate and stored in the dark at $4^{\circ} \mathrm{C}$ until tested and analysed.

\section{GC/MS analysis}

The analysis of the essential oil was performed using Thermoquest-Finnigan Trace GC-MS equipped with a DB-5 (5\% phenyl) methylpolysiloxane column $(60 \mathrm{~m} \backslash 0.25 \mathrm{~mm}$ i.d., film thickness $0.25 \mu \mathrm{m})$. The injection temperature was $220^{\circ} \mathrm{C}$ and the oven temperature was raised from $40^{\circ} \mathrm{C}(3 \mathrm{~min}$ hold $)$ to $250^{\circ} \mathrm{C}$ at a rate of $5^{\circ} \mathrm{C} \mathrm{min}{ }^{-1}$, then held at $250^{\circ} \mathrm{C}$ for $2 \mathrm{~min}$; transfer line temperature was $250{ }^{\circ} \mathrm{C}$. One $\mu \mathrm{L}$ of sample was injected and helium was used as the carrier gas at a flow rate of 1.0 $\mathrm{mL} \mathrm{min}^{-1}$. The mass spectrometer was scanned over the 40 to $500 \mathrm{~m} / \mathrm{z}$ with an ionizing voltage of $70 \mathrm{eV}$ and identification was based on standard mass library that National Institute of Standards and Technology (NIST) to detect the possibilities of essential oil components (Adams, 1989).

Antioxidant activity of Cypress essential oil using DPPH assay

DPPH assay was carried out as described by Brand-Williams et al. (1995). Various concentrations $\left(100-500 \mu \mathrm{g} \mathrm{mL}^{-1}\right)$ of the essential oil in dimethyl sulphoxide $(50 \mu \mathrm{L})$ were mixed with 5 $\mathrm{mL}$ of a $0.004 \%$ methanolic solution of DPPH. The mixtures were shaken, covered and left to stand for one hour in the dark. The absorbance was read against blank at $517 \mathrm{~nm}$. Ascorbic acid was used as reference compound.

The antioxidant capacity to scavenge the DPPH radical was calculated by the following equation:

$$
\text { Scavenging effect }(\%)=\left(A_{\text {blank }}-A_{\text {sample }}\right) / A_{\text {blank }} \times 100
$$

Where $A_{\text {blank }}$ is the absorbance of control reaction (containing each reagents except the sample), and $A_{\text {sample }}$ is the absorbance of sample.

The essential oil concentration providing 50\% inhibition $\left(\mathrm{IC}_{50} \mu \mathrm{g} \mathrm{mL}^{-1}\right.$ ) was calculated from the graph of percentage of scavenging activity against the essential oil concentration. Tests were carried out in triplicate.

\section{Anticancer activity}

\section{In vitro studies}

Three types of cancer cell lines were used in this study, human promyelocytic leukemia cell lines (HL-60 and NB4) and experimental animals model cancer cells (Ehrlish ascites carcinoma cells, EACC).

HL-60 and NB4 a human promyelocytic leukemia cell lines obtained from the American Type Culture Collection (ATCC), were cultured in RPMI 1640 medium supplemented with 10\% fetal bovine serum (FBS), $2 \mathrm{mmol} \mathrm{L}^{-1}$ glutamine, penicillin (100 $\mathrm{U} \mathrm{mL} L^{-1}$, and streptomycin $\left(100 \mu \mathrm{g} \mathrm{mL} L^{-1}\right)$ in humidified atmosphere containing $5 \% \mathrm{CO}_{2}$ at $37^{\circ} \mathrm{C}$ for $24 \mathrm{~h}$. Cell counts were determined. HL-60 and NB4 cells were seeded at a density of $3 \times 10^{5} \mathrm{~mL}^{-1}$. After that the cells were treated with different volumes of Cypress essential oil to give final concentrations (100, 200, 300, 400 and $500 \mathrm{ug} \mathrm{mL}^{-1}$ ) and incubated under the same condition for another $24 \mathrm{~h}$. The final volume in each experiment was made up to $100 \mu \mathrm{L}$ with the media containing $1 \%$ DMSO. Control cells were treated with the equivalent amount of vehicle dimethyl sulphoxide. After this period the cell viability was evaluated using trypan blue assay. The viability percentages were calculated according to Bennett et al. (1976). Each experiment was carried out in triplicate.

Experimental animals model cancer cell line (EACC) was maintained in the National Cancer Institute (NCI) Cairo, Egypt in female Swiss albino mice by weekly intraperitoneal transplantation of $2.5 \times 10^{6}$ cells. Similar line was preceded in the animal house for the same cells. For in vivo and in vitro studies, the cells were taken from tumor transplanted animals after 7 days of transplantation then the number of cells $\mathrm{mL}^{-1}$ was calculated by using appropriate microscope counting technique $\left(\approx 2 \times 10^{7}\right.$ cells $\left.\mathrm{mL}^{-1}\right)$. The cells were centrifuged at $1,000 \mathrm{rpm}$ for $5 \mathrm{~min}$, and then washed with saline. The number of cells needed to the test was prepared by suspending the cells in the appropriate volume of saline. The culture medium used was prepared using RPMI 1640 media, $10 \%$ fetal bovine serum, 2 mmol L glutamine, penicillin $\left(100 \mathrm{U} \mathrm{mL}^{-1}\right)$, and streptomycin $(100 \mu \mathrm{g}$ $\mathrm{mL}^{-1}$. The viability percentage of tumor cells was measured after incubation with the essential oil as well as saline and DMSO as control. Two $\mathrm{mL}$ of medium containing EACC $\left(2 \times 10^{6}\right.$ cells $)$ were transferred into a set of tubes, then different volumes of examined essential oil were added into the appropriate tube as well as control to give final concentrations 100, 200, 300, 400 and $500 \mu \mathrm{gLL}^{-1}$. The tubes were incubated at $37^{\circ} \mathrm{C}$ under $5 \%$ $\mathrm{CO}_{2}$ for $12 \mathrm{~h}$ then the viability percentage of tumor cells were measured by method of Bennett et al. (1976). Each experiment was carried out in triplicate.

The percentage of dead cells of each cell lines was plotted against the essential oil concentration to obtain the $\mathrm{LC}_{50}$.

\section{In vivo studies}

Animals

Thirty healthy female Swiss albino mice weighting 20-25 g (7-8 weeks old) were used throughout this experiment. The animals were obtained from the animal house of Helwan Station for Experimental Animals, Helwan, Egypt. They were raised in the animal house of Biochemistry Department, Faculty of Agriculture, Cairo University, Giza, Egypt. The animals were 
322

housed in polyethylene cages in groups of six mice per cage in a controlled environment condition $\left(25 \pm 2{ }^{\circ} \mathrm{C}, 50-60 \%\right.$ relative humidity and $12 \mathrm{~h} \mathrm{~d}^{-1}$ photoperiod). All animals were fed standard pellet diet and water ad libitum for two weeks (adaption period).

\section{Experimental design}

The animals were divided into five groups. First group served as normal control animals and was given corn oil orally for more than 12 weeks. $2^{\text {nd }}$ group, mice (tumor control) were transplanted intraperitoneal cavity with EACC at $1 \times 10^{6}$ cells $(0.2 \mathrm{~mL}) \cdot 3^{\text {rd }}$ group was treated with EACC (as in group 2$)$ and after one week of tumor transplantation (tumor induction period) mice were treated daily with Cypress essential oil $(75 \mathrm{mg}$ $\mathrm{kg}^{-1}$ body weight dissolved in corn oil orally) for the end of the experiment (post-initiation treatment). In group 4, mice were treated with EACC (as in group 2) and Cypress essential oil (75 $\mathrm{mg} \mathrm{kg}^{-1}$ body weight dissolved in corn oil orally). Essential oil treatment started after 24 hours of EACC transplantation (initiation treatment) and continued daily for the end of the experiment. Animals in group 5 for pre-initiating studies were treated daily with essential oil ( $75 \mathrm{mg} \mathrm{kg}^{-1}$ body weight dissolved in corn oil orally) for 2 weeks followed by EACC (as in group 2). Cypress treatment continued for the end of the experiment (preinitiation treatment). Antitumor effect of Cypress essential oil was evaluated by observing the changes with respect to EACC tumor number (all, viable and dead cells) was counted after $12 \mathrm{~d}$ of EACC transplantation (Bennett et al., 1976). The mean of survival time (MST) of each group consisting of 6 mice was monitored by recording the mortality daily. The MST of the treated group was compared with that of the tumor control group to calculate the increase in lifespan (ILS) according to Rajkapoor et al. (2004) using the following formula:

$$
\text { ILS }=[T-C] C \times 100
$$

Where $\mathrm{T}$ is the MST of treated group and C is the MST of tumor control group. Lactate dehydrogenase (LDH) activity was determined in the supernatant of tumor cell suspension (EACC) according to Legrand et al. (1992) and Young (2001).

\section{Biological effects of Cypress essential oil \\ Animals}

Twelve male Swiss albino mice weighting 20-25 g (7-8 weeks old) were used throughout this experiment. Mice obtained and adapted as in the previous experiment.

\section{Experimental design}

The animals were divided into two groups and each group contained six animals. The first group (normal control) was given corn oil orally. While in the second group, animals were treated daily with Cypress essential oil ( $75 \mathrm{mg} \mathrm{kg}^{-1}$ body weight) for three months to study the cytotoxicity (if any) induced by this essential oil. At the end of the experimental period, the animals were killed by cervical decapitation. Blood was collected. Serum was separated by centrifugation at $2500 \mathrm{rpm}$ at $37^{\circ} \mathrm{C}$ for 15 min.

\section{Biochemical analyses}

Serum glucose was determined according to Trinder (1969), total soluble proteins and albumin were determined according to
Hoffman (1966) and Tietz (1995) respectively. Globulin was calculated by difference between total protein and albumin. Triglycerides, total cholesterol, creatinine, uric acid, urea contents were determined according to Fossati and Prencipe (1982), Allain et al. (1974), Faulkner and King (1976), Tietz (1995) and First (2003) respectively. Aspartate aminotransferase (AST) and alanine aminotransferase (ALT) activities were measured in serum according to the method of Reitman and Frankel (1957). The activity of serum alkaline phosphatase (ALP) and Lactate dehydrogenase (LDH) activity were determined according to the method of Kind and King (1954) and Young (2001), respectively.

\section{Statistical analysis}

Data were subjected to an analysis of variance, and the means were compared using the Least Significant Difference (LSD) test at the 0.05 levels (Snedecor and Cochran, 1982).

\section{Results and Discussion}

\section{Chemical composition of Cypress essential oil}

The analysis of GC/MS of Cypress leaf essential oil (yield of $0.66 \pm 0.09 \%)$ resulted in the identification of 18 compounds representing 92.41\%. $\alpha$-pinene (29.21\%), $\delta 3$-carene (18.92\%), $\alpha$ cedrol (12.25\%), $\alpha$-terpinolene (7.66\%) and limonene (5.50\%) were the main components. All other components were present in amount lower than 5\%. Hydrocarbons were the main group, with oxygenated compounds as a minor fraction. The dominant compounds in Cypress oil were monoterpene hydrocarbons (69.39\%), followed by oxygenated sequiterpenes (12.25\%), sesquiterpene hydrocarbons (7.03\%) and oxygenated monoterpenes $(3.74 \%)$ (Table 1). These results are in agreement with Boukhris et al. (2012) who reported that Cypress essential oil contained mainly $\alpha$-pinene, $\delta 3$-carene, limonene and $\alpha$ terpinolene. Asgary et al. (2013) observed that $\alpha$-pinene and $\delta 3$ carene were the main components in C. sempervirens branchlet oil. However in a phytochemical study from Egypt, $C$. sempervirens leaf oil, the main constituent was cedrol followed by $\Delta 3$-carene, $\alpha$-pinene, limonene, $\alpha$-terpineolene (Elansary et al., 2012). Such compositional differences have been proven to be due to the geographic, climatic, harvest season and soil conditions which all cause fluctuations in the frequency of volatile constituents in given oil (Asgary et al., 2013).

Table 1. Chemical composition of leaf essential oil of $C$. sempervirens

\begin{tabular}{|c|c|c|c|c|c|}
\hline No & Components & $\%$ & No & Components & $\%$ \\
\hline 1 & $\alpha$-thujene & 0.33 & 10 & $\alpha$-Terpinolene & 7.66 \\
\hline 2 & $\alpha$-Pinene & 29.21 & 11 & 4-Terpineol & 2.53 \\
\hline 3 & Sabinene & 0.96 & 12 & Camphor & 0.85 \\
\hline 4 & $\beta$-Pinene & 1.35 & 13 & $\alpha$-Bornyl acetate & 1.95 \\
\hline 5 & Myrcene & 2.70 & 14 & B-Caryophyllene & 1.06 \\
\hline 6 & 83-Carene & 18.92 & 15 & $\alpha$-Humulene & 0.78 \\
\hline 7 & Limonene & 5.50 & 16 & Germacrene-D & 4.68 \\
\hline 8 & 1,8-Cineole & 0.36 & 17 & $\delta$-Cadinene & 0.51 \\
\hline 9 & $\gamma$-Terpinene & 0.81 & 18 & $\alpha$-Cedrol & 12.25 \\
\hline & $\begin{array}{c}\text { Total } \\
\text { identified }\end{array}$ & 92.41 & & & \\
\hline \multicolumn{2}{|c|}{$\begin{array}{l}\text { Monoterpene } \\
\text { hydrocarbons }\end{array}$} & 69.39 & \multicolumn{2}{|l|}{$\begin{array}{l}\text { Oxygenated } \\
\text { monoterpenes }\end{array}$} & 3.74 \\
\hline \multicolumn{2}{|c|}{$\begin{array}{l}\text { Sesquiterpene } \\
\text { hydrocarbons }\end{array}$} & 7.03 & \multicolumn{2}{|l|}{$\begin{array}{l}\text { Oxygenated } \\
\text { sesquiterpenes }\end{array}$} & 12.25 \\
\hline
\end{tabular}




\section{Antioxidant activity}

The antioxidant activity of Cypress essential oil at various concentrations was determined applying DPPH free radical scavenging assay and compared with that of the standard antioxidant ascorbic acid (Table 2). All the tested samples showed lower DPPH radical scavenging activity when compared with the ascorbic acid. The highest antioxidant scavenging effect (\%) was obtained with ascorbic acid $(94.80 \%)$ for concentration of $100 \mu \mathrm{g} \mathrm{mL}-1$, while it was $71.73 \%$ for $500 \mu \mathrm{g} \mathrm{mL}$ concentration of $C$. sempervirens essential oil.

The essential oil $\left(400 \mu \mathrm{g} \mathrm{mL}^{-1}\right)$ reduced the concentration of DPPH free radical with an efficacy near to $60 \mu \mathrm{g} \mathrm{mL}$ concentration of ascorbic acid. Essential oil was able to reduce the stable, purple-colored radical DPPH into yellow-colored DPPH reaching $50 \%$ of reduction with $\mathrm{IC}_{50}$ value $=290.09 \mu \mathrm{g} \mathrm{mL}^{-1}$, but it is still lower than ascorbic acid $\left(\mathrm{IC}_{50}=40.8 \mu \mathrm{g} \mathrm{mL}^{-1}\right)$. Nejia et al. (2013) showed antioxidant activities of Cypress by various antioxidant assays, including DPPH radical assay and ABTS assay. In the C. sempervirens oil, $\alpha$-pinene and $\delta$-3-carene were the major volatile components. Both these compounds along with other terpenoids have known antioxidant properties (Aazza $e t$ al., 2011). In the present study, all identified components were terpenoid derivatives, with monoterpene hydrocarbons as the major class of compounds. In a previous survey, Aazza et al. (2011) and Asgary et al. (2013) reported antioxidant activities for the essential oil obtained from the aerial parts of $C$. sempervirens using DPPH free-radical scavenging, thiobarbituric acid reactive species and ferric reducing power assays.

The antioxidant activity of essential oil could be assigned to the synergistic effects of two or more compounds present in the oil. In this context, Boukhris et al. (2012) mentioned that most natural antioxidative compounds often work synergistically with each other to produce a wide spectrum of antioxidative properties that create an effective defense system against free radicals.

\section{In vitro anticancer activity}

In order to investigate the effect of $C$. sempervirens essential oil on human promyelocytic leukemia and experimental animal model cancer cells, in vitro experiments were conducted using cultured HL-60, NB4 and EACC cell lines. Results of the viability were assessed by trypan blue assay. The results found that the incubation of HL-60 and NB4 cells with Cypress essential oil at various concentrations reduced the viability of these cells. The

Table 2. Antioxidant activities of $C$. sempervirens essential oil using DPPH radical

\begin{tabular}{cc}
\hline Conc. $\left(\mu \mathrm{g} \mathrm{mL}^{-1}\right)$ & DPPH scavenging activity $(\%)$ \\
\hline C. sempervirens & $19.33 \pm 1.86^{\mathrm{f}}$ \\
100 & $42.77 \pm 3.03^{\mathrm{e}}$ \\
200 & $56.77 \pm 3.68^{\mathrm{d}}$ \\
300 & $65.83 \pm 4.35^{\mathrm{c}}$ \\
400 & $71.73 \pm 0.93^{\mathrm{c}}$ \\
500 & \\
Ascorbic acid & $24.80 \pm 0.82^{\mathrm{f}}$ \\
20 & $52.93 \pm 3.62^{\mathrm{d}}$ \\
40 & $74.40 \pm 2.40^{\mathrm{c}}$ \\
60 & $86.23 \pm 3.04^{\mathrm{b}}$ \\
80 & $94.80 \pm 2.39^{\mathrm{a}}$ \\
\hline 100 &
\end{tabular}

The values are means \pm SE. The mean values with different small letters within a column indicate significant differences $(\mathrm{p} \leq 0.05)$. dead cells were increased by increasing the concentration of Cypress essential oil (Table 3).

The highest HL-60, NB4 and EACC dead cell (\%) was recorded by $500 \mathrm{\mu g} \mathrm{mL}^{-1}$ Cypress essential oil. It must be noticed that, there were no significant difference in dead cells (\%) of HL60, NB4 and EACC cell line between the concentrations 400 and $500 \mu \mathrm{g} \mathrm{mL} L^{-1}$. The Cypress essential oil showed potent cytotoxic effects with the $\mathrm{LC}_{50}$ values of $365.41,333.79$ and $372.43 \mu \mathrm{g} \mathrm{mL}{ }^{-1}$ for HL-60, NB4 and EACC cell lines, respectively. The $\mathrm{LC}_{50}$ values indicated that the anticancer activity of Cypress essential oil against NB4 cell line was higher than HL-60 and EACC cell lines.

\section{In vivo anticancer activity}

The effect of C. sempervirens essential oil post-initiation, initiation and pre-initiation treatments on survival of tumor (EACC) transplanted female mice are shown in Table 4. The mean survival days (MST) for the untreated tumor control group were $12.17 \pm 0.31$ days. The $C$. sempervirens essential oil treatments of tumor (EACC) transplanted female mice significantly $(\mathrm{p} \leq 0.05)$ increase MST when compared with tumor control. It was found that $C$. sempervirens essential oil was more effective during pre-initiation treatment than initiation and post-initiation treatments respectively. The highest mean survival time (days) was recorded by pre-initiation treatment (29.83 days) followed by initiation treatment (20 days). A low effect of post-initiation treatment on MST of tumor transplanted animals was found. The highest increase in lifespan was observed by pre-initiation group $(145.11 \%)$ compared to tumor group. There was highly significant $(\mathrm{p} \leq 0.05)$ reduction in the tumor cells number of initiation and pre-initiation treatments (20.92\% and 36.73\%) when compared with tumor control. No significant change in tumor cells number was found between post-initiation treatment and tumor control group. On the other hand, there was significant $(\mathrm{p} \leq 0.05)$ increase in dead cells (\%) in all treated groups comparing with tumor control group. The highest dead cells (\%) was recorded by initiation treatment $(18.05 \%)$ followed by pre-initiation treatment (17.91\%) comparing with tumor control. These results confirmed with that of LDH activity in the supernatant of tumor cell suspension. Cells that have lost membrane integrity release lactate dehydrogenase (LDH) into the surrounding medium. Measure the release of $\mathrm{LDH}$ from damaged cells gives an indicator of cytotoxicity (Hernandez et al., 2003). The results indicated that the increase in dead cells increases LDH activity in supernatant of tumor suspension. The highest significant ( $\mathrm{p} \leq$ 0.05 ) increase in LDH activity was observed by pre-initiation treatment followed by initiation treatment comparing with tumor control. Generally, it was shown that the pre-initiation treatment was more effective than initiation and post-initiation

Table 3. In vitro anticancer activity of $C$. sempervirens essential oil against

\begin{tabular}{crcc}
\hline \multirow{2}{*}{ Extract $\left(\mu \mathrm{gmL} L^{-1}\right)$} & \multicolumn{3}{c}{ Deadcells $(\%)$} \\
\cline { 2 - 4 } & HL-60 & NB4 & EACC \\
\hline 100 & $21.33 \pm 2.03^{\mathrm{c}}$ & $19.40 \pm 1.56^{\mathrm{c}}$ & $11.30 \pm 2.76^{\mathrm{c}}$ \\
200 & $29.57 \pm 2.42^{\mathrm{bc}}$ & $32.67 \pm 2.61^{\mathrm{b}}$ & $19.50 \pm 5.82^{\mathrm{c}}$ \\
300 & $36.00 \pm 2.52^{\mathrm{b}}$ & $36.40 \pm 3.37^{\mathrm{b}}$ & $43.63 \pm 5.29^{\mathrm{b}}$ \\
400 & $57.50 \pm 3.04^{\mathrm{a}}$ & $64.70 \pm 3.89^{\mathrm{a}}$ & $54.82 \pm 5.72^{\mathrm{ab}}$ \\
500 & $66.78 \pm 4.27^{\mathrm{a}}$ & $73.23 \pm 4.23^{\mathrm{a}}$ & $58.77 \pm 1.46^{\mathrm{a}}$ \\
\hline
\end{tabular}

HL-60, NB4 and EACC cell lines

The values are means $\pm S E$. The mean values with different small letters within a column indicate significant differences $(p \leq 0.05)$. 
324

Table 4. Effect of C. sempervirens essential oil treatment on the MST, EACC number and LDH activity of tumor transplanted female mice

\begin{tabular}{lccccc} 
Treatment & MST & ILS $(\%)^{*}$ & No.Cells mL ${ }^{-1} \times 10^{6}$ & Dead cells $(\%)$ & LDH $\left.(\mathrm{UL})^{-1}\right)$ \\
\hline Normal control & $>90$ day & $>639$ & - & - & - \\
Tumor control & $12.17 \pm 0.31^{\mathrm{c}}$ & - & $437.33 \pm 25.20^{\mathrm{a}}$ & $3.68 \pm 0.43^{\mathrm{c}}$ & $11.11 \pm 0.54^{\mathrm{d}}$ \\
Post-initiation & $14.33 \pm 1.02^{\mathrm{c}}$ & 17.75 & $431.66 \pm 21.66^{\mathrm{a}}$ & $6.86 \pm 0.93^{\mathrm{b}}$ & $14.51 \pm 1.29^{\mathrm{c}}$ \\
Initiation & $20.00 \pm 1.12^{\mathrm{b}}$ & 64.34 & $345.84 \pm 18.19^{\mathrm{b}}$ & $18.05 \pm 0.90^{\mathrm{a}}$ & $22.08 \pm 1.37^{\mathrm{b}}$ \\
\hline Pre-initiation & $29.83 \pm 1.08^{\mathrm{a}}$ & 145.11 & $276.70 \pm 13.82^{\mathrm{c}}$ & $17.91 \pm 1.07^{\mathrm{a}}$ & $26.63 \pm 0.90^{\mathrm{a}}$ \\
\hline
\end{tabular}

The values are means \pm SE. The mean values with different small letters within a column indicate significant differences $(\mathrm{p} \leq 0.05)$.

* Relative to tumor control.

treatments respectively on the tumor (EACC) transplanted female mice. This may recommended the use of this essential oil as preventive agent against tumor.

Few studies on anticancer activities of $C$. sempervirens essential oil have been performed until now. Bayala et al. (2014) and Loizzo et al. (2008) reviewed the antiproliferative effects of Cypress leaf essential oil, and showed that the Cypress essential oil was effective in inhibiting human amelanotic melanoma cells (C32) with an $\mathrm{IC}_{50}$ value of $104.9 \mu \mathrm{g} \mathrm{mL}$. Loizzo et al. (2008) found that $\beta$-caryophyllene and $\alpha$-cedrol were found to be active on human renal adenocarcinoma and amelanotic melanoma cell lines. The results of this study are in accordance with previous study, which has reported that $\alpha$-pinene as the major components in Cypress essential oil demonstrated strong cytotoxicity towards rat brain cancer cell line $(\mathrm{N} 2 \mathrm{a}$ neuroblastoma cells). Significant decreases were observed in $\mathrm{N} 2 \mathrm{a}$ cells at 100, 200 and $400 \mu \mathrm{g} \mathrm{mL}^{-1}$ (Aydin et al., 2013). Also, Matsuo $e t$ al. (2011) revealed that $\alpha$-pinene was able to induce apoptosis evidenced by early disruption of the mitochondrial potential, production of reactive oxygen species, and increase in caspase- 3 activity in B16F10 murine melanoma cell. $\alpha$-Pinene and $\beta$-pinene showed cytotoxicity on SK-OV-3, HO-8910, Bel7402, A549, HepG2, MCF-7 and A375 cancer cell lines (Sobral et al., 2014). Ji et al. (2006) demonstrated that induction of apoptosis by limonene was mediated by a caspase dependent mitochondrial death pathway in human leukemia cells. Furthermore, limonene induced apoptosis in HL-60 cells through activation of caspase-8 (Kawamori et al., 1996). Chen et al. (1998) suggested that the anticancer activity of limonene might be related to inhibition of the membrane association of P21ras protein and increased gap junction intercellular communication. An additional recent study indicated that terpinolene reduced the protein expression of AKT1 in K562 human leukemic cells and inhibited cell proliferation (Okumura et al., 2012). In contrast, Sobral et al. (2014) reviewed that camphor, 4-terpineol, $\gamma$-terpinene, 1,8-cineole and myrcene which found in small quantity in Cypress essential oil under investigation in this study had antitumor activity against several human, mouse and rat cancer cell lines with different mechanisms such induction of apoptosis and inhibition of the NF-kB pathway.

\section{Toxicity of Cypressessential oil}

This part of study was performed to evaluate the toxicity of Cypress essential oil to be used as antioxidant and anticancer agents. Table 5 demonstrated the biological effects of Cypress essential oil on normal mice. After subjecting the mice to a daily treatment of $C$. sempervirens essential oil for three months, the animals expressed some changes in their biochemical parameters. No death was observed during this treatment.
The oral administration of Cypress essential oil to mice showed no significant changes in serum glucose, total protein, albumin, globulin, triglycerides and uric acid; while total cholesterol and creatinine significantly $(\mathrm{p} \leq 0.05)$ decreased, however urea was significantly $(\mathrm{p} \leq 0.05)$ increased when compared with normal control group.

Regarding the study of the effects of $C$. sempervirens essential oil on some serum enzymes, it was observed that the oil caused a significant increase in transaminases (ALT and AST) levels. Compared to the control value of ALT $\left(17.12 \mathrm{IU} \mathrm{L}^{-1}\right)$ and AST $\left(25.90 \mathrm{IU} \mathrm{L}^{-1}\right)$, the essential oil marked a significant increase of $24.05 \mathrm{IU} \mathrm{L}^{-1}$ and $33.73 \mathrm{IU} \mathrm{L}^{-1}$ levels of the respective enzymes. In connection, significant increase in serum LDH activity as affected by oral administration with essential oil to mice was found. The activity of serum alkaline phosphatase was not significantly different $(p \leq 0.05)$ from the control after the oil treatment. In fact, all the obtained values in both groups were within the normal range according to Mitruka and Rawnsley (1979).

The serum proteins are useful parameters to indicate impairment in the functional capacity of the liver and kidney. In this study no alteration in the levels of total protein, albumin and globulin was found.

Urea and creatinine are nitrogenous end products of metabolism. The urea and creatinine are screening tests of renal function. Because they are handled primarily by glomerular filtration with little or no renal regulation or adaptation in the course of declining renal function (Kamal, 2014). The significant increase in serum urea concentration may be attributed to impairment and indicates renal dysfunction (Yakubu et al., 2003). Significant decrease in creatinine content in Cypress

Table 5. Serum biochemical parameters of normal male mice treated with C. sempervirens essential oil

\begin{tabular}{|c|c|c|}
\hline Biochemical parameters & Normal control & C. sempervirens \\
\hline Glucose $\left(\mathrm{mg} \mathrm{dL}^{-1}\right)$ & $88.93 \pm 4.44$ & $82.91 \pm 2.26$ \\
\hline Total protein $\left(\mathrm{g} \mathrm{dL}^{-1}\right)$ & $4.91 \pm 0.25$ & $4.82 \pm 0.24$ \\
\hline Albumin $\left(\mathrm{g} \mathrm{dL}^{-1}\right)$ & $3.00 \pm 0.15$ & $2.64 \pm 0.09$ \\
\hline Globulin $\left(\mathrm{g} \mathrm{dL}^{-1}\right)$ & $1.91 \pm 0.30$ & $2.18 \pm 0.35$ \\
\hline Triglycerides $\left(\mathrm{mg} \mathrm{dL}^{-1}\right)$ & $127.07 \pm 5.23$ & $120.71 \pm 6.74$ \\
\hline Total cholesterol $\left(\mathrm{mg} \mathrm{dL}^{-1}\right)$ & $63.5 \pm 2.25$ & $50.80 \pm 2.15^{\circ}$ \\
\hline Creatinine $\left(\mathrm{mg} \mathrm{L}^{-1}\right)$ & $10.57 \pm 0.59$ & $8.08 \pm 0.54^{*}$ \\
\hline Uric acid $\left(\mathrm{mg} \mathrm{dL}^{-1}\right)$ & $3.57 \pm 0.26$ & $3.85 \pm 0.16$ \\
\hline Urea $\left(\mathrm{mg} \mathrm{dL}^{-1}\right)$ & $13.28 \pm 0.57$ & $14.35 \pm 0.30^{\circ}$ \\
\hline $\operatorname{ALT}\left(\mathrm{IU} \mathrm{L}^{-1}\right)$ & $17.12 \pm 0.93$ & $24.05 \pm 1.76$ \\
\hline $\operatorname{AST}\left(\mathrm{IU} \mathrm{L}^{-1}\right)$ & $25.90 \pm 1.13$ & $33.73 \pm 2.44^{\circ}$ \\
\hline $\operatorname{ALP}\left(\mathrm{IU} \mathrm{L}^{-1}\right)$ & $42.50 \pm 3.42$ & $45.70 \pm 2.73$ \\
\hline $\operatorname{LDH}\left(\mathrm{U} \mathrm{L}^{-1}\right)$ & $111.04 \pm 5.14$ & $134.93 \pm 4.19^{\circ}$ \\
\hline
\end{tabular}

The values are means \pm SE. ${ }^{*}$ a significant difference $(\mathrm{p} \leq 0.05)$ compared with normal control group. 
group was found that indicate no toxicity of the essential oil on the muscle and kidneys. Therefore, the effect produced by Cypress essential oil on the indices of kidney damage investigated in this study suggests toxicity.

The serum levels of both AST and ALT rise whenever there is liver cell damage. The higher activities of both enzymes reflect the greater degree of liver damage (Eteng et al., 2009). An increased serum activity of these enzymes in the present study indicates that the Cypress essential oil may have cytotoxic effects on the liver. The extract could affect the permeability of the cell membrane causing the membrane to become leaky. This would then induce the release of these enzymes from the cells into the blood stream, thereby causing the subsequent serum elevation of the enzymes.

Activity of LDH is present in almost all cells of the body and is found only in the cytoplasm of the cell. The activities of isoenzymes are present in brain, kidney, liver, lung, lymph nodes, myocardium, skeletal muscle, spleen, erythrocytes, leucocytes, and also platelets (Drent et al., 1996). Enzyme levels in various tissues are very high compared to those in serum. Thus, tissue levels are about 500 fold higher than those normally found in serum, and leakage of the enzyme from even a small mass of damaged tissue can increase the observed serum level of LDH to a significant extent (Wills, 1985). Therefore, the increase in serum LDH activity of Cypress group may indicate tissue damage leading to leakage of tissue enzyme to the serum. The result of the present study has shown that the oil of Cypress is of mild toxicity. The study of possible toxic effects of Cupressus sempervirens leaf essential oil is herein being reported for the first time.

\section{Conclusions}

The results of this work show that the Cupressus sempervirens leaf essential oil possesses antioxidant and anticancer properties, which can be used as a natural antioxidant and anticancer agent, taking into consideration the mild toxicity of Cypress essential oil. However, further studies are necessary to elucidate the mechanism of action of Cypress oil. Also, haematological and histological studies must be carried out on experimental animals.

\section{Acknowledgments}

This work was supported by the Cairo University Research Park (CURP), Faculty of Agriculture, Cairo University.

\section{References}

Aazza S, Lyoussi B, Miguel MG (2011). Antioxidant and antiacetylcholinesterase activities of some commercial essential oils and their major compounds. Molecules 16:7672-7690.

Adams RP (1989). Identification of essential oils by ion trap mass spectroscopy. Academic press, New York.

Alkurdi MIS, Supuka J (2015). Assessment of Cupressus sempervirens L. hardiness through carbohydrates and pigments content in the leaves. ActaScientiarum Polonorum Formatio Circumiectus 14:3-16.

Allain CC, Poon LS, Chan CS, Richmoud W, Fu PC (1974). Enzymatic determination of total serum cholesterol. Clinical Chemistry 20:470-
475.

Amouroux P, Jean D, Lamaison J (1998). Antiviral activity in vitro of Cupressus sempervirens on two human retroviruses HIV and HTLV. Phytotherapy Research 12:367-369.

Asgary S, Naderi GA, Ardekani MR, Sahebkar A, Airin A (2013). Chemical analysis and biological activities of Cupressus sempervirens var. horizontalis essential oils. Pharmaceutical Biology 51:137-144.

Aydin E, Türkez H, Geyikoğlu F (2013). Antioxidative, anticancer and genotoxic properties of $\alpha$-pinene on N2a neuroblastoma cells. Biologia 68:1004-1009.

Bayala B, Bassole IH, Scifo R, Gnoula C, Morel L (2014). Anticancer activity of essential oils and their chemical components - a review. American Journal ofCancer Research 4:591-607.

Bennett JM, Catovsky D, Danniel MT, Galton DAG, Graanlnik HR, Sultan C (1976). Proposal for the classification of the acute leukemias. British Journal of Haematology 33:451-458.

Boukhris M, Regane G, Yangui T, Sayadi S, Bouaziz M (2012). Chemical composition and biological potential of essential oil from Tunisian Cupressus sempervirens L. Journal of Arid Land Studies 22:329-332.

Brand-Williams W, Cuvelier ME, Berset CLWT (1995). Use of a free radical method to evaluate antioxidant activity. LWT-Food Science and Technology 28(1):25-30.

Chen X, Shuzo O, Li Y, Han R (1998). Effect of d-limonene, Salvia miltiorrhiza and turmeric derivatives on membrane association of $R a s$ gene product and gap junction intercellular communication. Acta PharmaceuticaSinica 33:821-827.

Drent M, Cobben NAM, Henderson RF, Wouters EFM, van DieijenVisser M (1996). Usefulness of lactate dehydrogenase and its isoenzymes as indicators of lung damage or inflammation. European Respiratory Journal 9:1736-1742.

Duke JA (2008). Duke's Handbook of Medicinal Plants of the Bible. CRC Press, New York, pp 160-162.

Elansary HO, Salem MZ, Ashmaw NA, Yacout MM (2012). Chemical composition, antibacterial and antioxidant activities of leaves essential oils from Syzygium cumini L., Cupressus sempervirens L. and Lantana camara L. from Egypt.Journal of Agricultural Science 4:144152.

Emami SA, Asgary S, Naderi GA, Shams MR, Kasher T (2011). Antioxidant activities of Juniperus foetidissima essential oils against several oxidative systems. Revista Brasileira de Farmacognosia 21:627-634.

Eteng MU, Ibekwe HA, Abolaji AO, Okoi AI, Onwuka FC (2009). Effect of Rauwolfia vomitoria Afzel (Apocynaceae) extract on serum amino transferase and alkaline phosphatase activities and selected indices of liver and kidney functions. African Journal of Biotechnology 8:46044607.

FaulknerWR, KingJW (1976). Fundamental of clinical chemistry. In: Tiezz NW(Ed).Saunders WB, Philadelphia pp 994998.

First MR (2003). Clinical chemistry: Theory, analysis, correlation. In: Kaplan LA, Pesce AJ, Kazmierczak SC (Eds). Renal function. $4^{\text {th }}$ ed, Mosby Inc StLouispp 477.

Fossati P, Prencipe L (1982). The determination of triglyceride using enzymatic methods. Clinical Chemistry 28:2077-2080.

Hanahan D, Weinberg RA (2011). Hallmarks of cancer: the next generation. Cell 144:646-674. 
326

Hernandez JM, Bui MH, Han KR, Mukouyama H, Freitas DG (2003). Novel kidney cancer immunotherapy based on the granulocytemacrophage colony-stimulating factor and carbonic anhydrase IX fusion gene. Clinical Cancer Research 9:1906-1916.

Hoffman WS (1966). The Biochemistry of Clinical Medicine. $3^{\text {rd }}$ ed, Year Book. Medical publishers, Chicago pp 33.

Ji J, Zhang L, Wu Y,Zhu X, Lv S, Sun X (2006). Induction of apoptosis by $\mathrm{d}$-limonene is mediated by a caspase dependent mitochondrial death pathway in human leukemia cells. Leukemia Lymphoma 47:26172624.

Kamal A (2014). Estimation of blood urea (bun) and serum creatinine level in patients of renal disorder. Indian Journal of Fundamental and Applied LifeSciences 4:199-202.

Kawamori T, Tanaka T, Hirose Y, Ohnishi M, Mori H (1996). Inhibitory effects of d-limonene on the development of colonic aberrant crypt foci induced by azoxymethane in F344 rats. Carcinogenesis 17:369-372.

Kind PR, King EJ (1954). Estimation of plasma phosphatase by determination of hydrolyzed phenol with amino antipyrine. Journal of Clinical Pathology 7:322-326.

Lang G, Buchbauer G (2012). A review on recent research results (20082010) on essential oils as antimicrobials and antifungals. A review. Flavour and Fragrance Journal 27:13-39.

Legrand C, Bour JM, Jacob C, Capiaumont J, Martial A (1992). Lactate dehydrogenase $(\mathrm{LDH})$ activity of the number of dead cells in the medium. Journal of Biotechnology 25:231-243.

Loizzo MR, Tundis R, Menichini F, Saab AM, Statti GA (2008). Antiproliferative effects of essential oils and their major constituents in human renal adenocarcinoma and amelanotic melanoma cells. Cell Proliferation 41:1002-1012.

Mani S (2015). Production of reactive oxygen species and its implication in human diseases. In: Rani V, Yadav UCS (Eds). Free radicals in human health and disease. Springer, New Delhi, India, pp 3-16.

Matsuo AL, Figueiredo CR, Arruda DC, Pereira FV, Scutti JAB (2011). aPinene isolated from Schinus terebinthifolius Raddi (Anacardiaceae) induces apoptosis and confers antimetastatic protection in a melanoma model. Biochemical and Biophysical Research Communications 411:449-454.

Mitruka BM, Rawnsley HM (1979). Clinical biochemical and hematological reference values in normal experimental animals and normal humans. ${ }^{\text {nd }}$ Ed. MSSON Publishing, USA.

Nejia H, Séverine C, Jalloul B, Mehrez R, Stéphane CJ (2013). Extraction of essential oil from Cupressus sempervirens: comparison of global yields, chemical composition and antioxidant activity obtained by hydrodistillation and supercritical extraction. Natural Product Research 27(19):1795-1799.
Okumura N, Yoshida H, Nishimura Y, Kitagishi Y, Matsuda S (2012). Terpinolene, a component of herbal sage, downregulates AKT1 expression in K562 cells. Oncology Letters 3:321-324.

Pham-Huy LA, He H, Pham-Huy C (2008). Free radicals, antioxidants in disease and health. International Journal of Biomedical Science 4:89-96.

Rajkapoor B, Jayakar B, Murugesh N (2004). Antitumor activity of Indigofera aspalathoides on Ehrlich ascites carcinoma cells in mice. Indian Journal of Pharmacology 36:38-40.

Reitman S, Frankel S (1957). A colourimetric method for the determination of serum glutamic oxaloacetic and glutamic pyruvic transaminases. American Journal ofClinical Pathology 28:56-62.

Seelinger M, Popescu R, Giessrigl B, Jarukamjorn K, Unger C (2012). Methanol extract of the ethnopharmaceutical remedy Smilax spinosa exhibits anti-neoplastic activity. International Journal of Oncology 41:11641172.

Sies H (1986). Biochemistry of oxidative stress. Angewandte Chemie International Edition 25:1058-1071.

Snedecor GW, Cochran WG (1982). Statistical Methods. The Iowa State Univ Press, Ames, Iowa, USA, p 507.

Sobral MV, Xavier AL, Lima TC, de Sousa DP (2014). Antitumor activity of monoterpenes found in essential oils. The Scientific World Journal doi.org/10.1155/2014/953451.

Song Y, Sun H, Zhang A, Yan G, Han Y, Wang X (2014). Plant-derived natural products as leads to anti-cancer drugs. Journal of Medicinal Plant and Herbal Therapy Research 2:6-15.

Tapondjou AL, Adler C, Fontem DA, Bouda H, Reichmuth C (2005). Bioactivities of cymol and essential oils of Cupressus sempervirens and Eucalyptus saligna against Sitophilus zeamais Motschulsky and Tribolium confusum. du Val.Journal of Stored Products Research 41:91102.

Tietz NW (1995). Clinical guide to laboratory tests. $3^{\text {rd }}$ ed. Philadelphia: WB Saunders pp 22-25.

Trinder P (1969). Enzymatic determination of glucose in blood serum. Annals of Clinical Biochemistry 6:2426.

Wills DE (1985). Biochemical basis of medicine. $3^{\text {rd }}$ ed, John Wright and Sons Ltd, Bristol, England pp 267-268.

Wishart DS (2015). Is Cancer a Genetic Disease or a Metabolic Disease? EBioMedicine 2:478-479.

Yakubu MT, Bilbis LS, Lawal M, Akanji MA (2003). Evaluation of selected parameters of rat liver and kidney function following repeated administration of yohimbine. Biokemistri 15:50-56.

Young DS (2001). Effects of Disease on Clinical Laboratory Tests. $4^{\text {th }} \mathrm{ed}$. Washington,DC: American Association for Clinical Chemistry. 